\title{
INTERNATIONAL TOURISM AND THE COVID-19 PANDEMIC: THE USE OF VIRTUAL REALITY TO INCREASE TOURISM DESTINATION SUSTAINABILITY AND HOW USERS PERCEIVE THE AUTHENTICITY OF VR EXPERIENCES
}

\author{
Eunike M. Gegung \\ Alumni Master in Tourism Business and Destination Management \\ Victoria University Business School \\ 300 Flinders St, Melbourne VIC 3000, Australia \\ eunikegegung@gmail.com
}

Diterima: 28 Pebruari 2021. Disetujui: 24 Mei 2021. Dipublikasikan: 28 Juni 2021

\begin{abstract}
This paper aims to analyze the use of virtual reality (VR) in the wake of the COVID-19 pandemic to increase destination sustainability and explore the authenticity of VR experiences as a substitute for real-life experiences. It begins by giving a brief background of the effect of the COVID 19 crisis on the tourism industry. Then archival research or document review is used to collect the data, it may, therefore, be analyzed through a thematic and content analysis. This paper showed VR as a viable instrument to promote the sustainability of tourist destinations not only from an environmental and cultural perspectives but also from the economic aspect of host communities through the development of alternate forms of income. Moreover, the use of VR may mitigate the possibility of virus spreading, increase destination sustainability and provide another option for a wider audience of visitors to see how prospective and worthy the sites are.
\end{abstract}

Keywords: Authenticity, COVID-19, sustainability, tourism destinations

(C) 2021 Direktorat Kajian Strategis

\section{INTRODUCTION}

Coronavirus was earlier noticed in 1918, known as a flu pandemic or Spanish flu. In 2002, severe acute respiratory syndrome coronavirus (SARS-CoV) was identified in Guangdong, China. During this outbreak, more than 8000 people from 29 countries were confirmed infected and 774 people died (Wang et al., 2018). This SARS$\mathrm{CoV}$ was then contained in May 2004. Later, around 2012, another form of Coronavirus was onset in Saudi Arabia and was named as Middle East respiratory syndrome coronavirus
(MERS-CoV) causing more than 858 people to die because of infection and complication (WHO, n.d.). The latest form of coronavirus or novel coronavirus (COVID -19) evolves and becomes transmissible from human to human and can be transmitted while infected people did not show any symptoms (Edwards, 2020). This virus is extremely contagious and spreads swiftly and ceaselessly in the global population (Liu et al., 2020). According to WHO (2021), the confirmed cases of the COVID 19 have increased significantly to $112,902,746$ and caused more than 2 million deaths. To slow down the transmission of this 
infectious disease. Many countries have adopted lockdown procedures and travel restrictions to shrink the number of confirmed cases and the death rates. These procedures have reduced the number of international visitors.

According to UNWTO (2020), Travel and Tourism are the most impacted sectors during this unprecedented global health emergency. The number of international visitors declined almost three-fourths (72\%) from January to October 2020. This reduction has also impacted export revenues of international tourism at 935 billion. This was 10 times larger than that of in 2009 where the global economic crisis occurred (UNWTO, n.d.).

According to the data obtained from UNWTO (n.d.), there are at least five factors that have weighed the recovery of international tourism during the pandemic. These are travel restrictions with the highest proportion at around four-fifths $(79 \%)$, followed by slow virus containment that stood at $68 \%$, economic environment, and lack of coordinated responses among the countries which was a compromise of $38 \%$ and $37 \%$ respectively. Next was slow consumer confidence $31 \%$ and slow flight resumption $20 \%$, and others at $4 \%$.

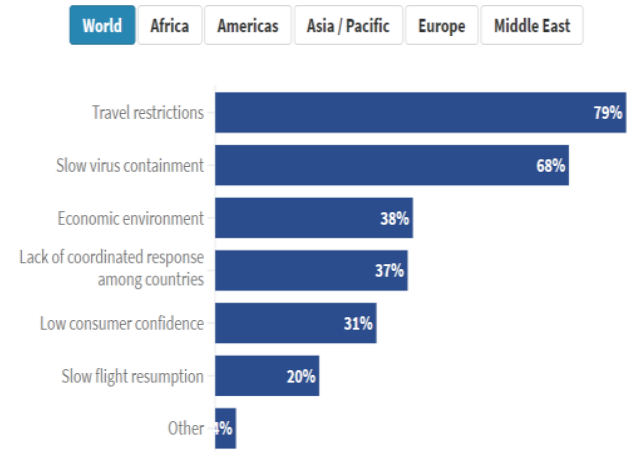

Figure 1. The main factors affecting International Tourism recovery (Source: UNWTO n.d.)
This then leads to the question of when will tourism activities go back to normal. The term virtual reality has been touted as an alternative solution that can be used to increase the destination's adaptability and continuity at the same time to enhance its competitive advantage during the pandemic. Virtual reality refers to a computer-generated simulation (Mitchell, 2020). This artificial intelligence generates a dynamic three-dimensional object that simulates artificial environments where users may see the sites in a holistic manner (Mitchell, 2020). Following are some studies that discussed the use of virtual reality in tourism destination areas, including its implication. The first one is, Shaikh et al., (2018) previous research found that there are some benefits and drawbacks of using VR applications. It is said that VR may act as an instrument in providing another dimension that enables tourists to experience destinations through the application. The use of 360-degree videos and images may enhance tourist experiences towards the vacation spots (Shaikh et al., 2018). Though, the importance of the human senses and the concepts of immersion and presence need to be scrutinized at some point. Another research related to the use of VR-related tourism activities is done by Guttentag (2010). This article evolves the idea of tourist's attitudes towards the authenticity of VR-related tourism activities.

It could be argued that this technological innovation may eliminate the possibility of the virus spreading and transform the destination into more resilient. However, is it true that this virtual reality can inspire and substitute a real experience for its users? (Guttentag, 2010; Shaikh et al., 2018). Therefore, this paper will consider some arguments related to the idea of virtual reality in the wake of the pandemic and how it may 
support destination sustainability, along with the perception of authenticity of virtual reality experiences.

\section{METHOD}

In conducting the study and gathering the most appropriate data, the qualitative research method was used in this paper. This method is used to scrutinize the quality of relationships, situations, activities, or materials (Fraenkell, 2012, as cited in Agustina \& Yoshinta, 2020). A systematic review is used to aggregate or summarise, and also to explain, analyze, or classify the phenomenon (Fraenkel et al., 2012). Moreover, the data was collected and explored through Library research for about one and a half months, from earlier January to mid of February 2021. This method utilizes the earlier existing infallible documents and similar sources of information. This means the data was collected by analyzing written evidence as primary sources such as documents, journal articles, scholarly books, research reports, online sources, media releases, and government reports (de Falco et al., 2019, as cited in Chirisa et al., 2020).

Then, a thematic content analysis was applied for assembling and structuring the data thematically (Chirisa et al., 2020). Thematic content analysis is referencing the use of textual material in research to analyze the text and social investigation within several empirical methods (Kumar et al., 2020, as cited in Chirisa et al., 2020). Therefore, using this method can bring out the idea of VR in the wake of the pandemic and how it may support destination sustainability, along with the perception of authenticity of this application.

\section{RESULTS AND DISCUSSION}

\section{Destination sustainability implications}

Tourism is among the affected sectors that are facing challenges during the COVID-19 pandemic (Itani \& Hollebeek, 2021). Therefore, to recover from this situation, it is necessary to obtain travelers confidence by ensuring that their health is protected (Sera \& Leong, 2020). In dealing with this situation, it requires a shifting from physical to touchless travel which involves sustainability, technology, health, and securities (Schiopu et al., 2021). The idea of virtual reality may support those causes. This is because VR may rejuvenate tourism destinations into more green, inclusive, and resilient compared to the traditional way of visiting the place (Schiopu et al., 2021). As might be expected the traditional tourism model may involve a great number of visitors moving from one destination to another, which then generates carbon emissions, also extra lands and water needed for tourism activities. Virtual reality promotes the continuity of destination areas. It may lessen the impact of tourism activities taking place in nature especially during the pandemic. This statement is supported through a study done by Newsome (2020) who said that during the global pandemic, the environment has changed with the most noticeable effect. The reduction in carbon emission and air pollution has been captured from satellites (NASA, 2020 as cited in Newsome, 2020). Specifically, air quality has been seen much better in China and Europe (Newsome, 2020).

In addition to this, virtual reality may offer alternative forms of access to threatened locations and remote areas where visitors might not be able to visit (Schaffer et al., 2018). Take Maya Bay, for instance, due to mass tourism that has threatened marine life, local authorities have closed the site. Virtual reality could offer experiences of locations without 
impacting the natural environment (Schaffer et al., 2018).

What is more, virtual tourism may also prevent excessive tourism in favorable destinations where real-life tourism may degrade the sustainability aspects of local cultures, historical icons and often generate anti-tourist attitudes growth among host communities. Loads of tourists may induce assimilation and inadvertently weaken the authenticity of the indigenous cultures by which a local culture may lose many of its core elements. Also, cultural commodification has become another issue, where tourism turns local cultures into the commodity (Shepherd, 2002). As often this culture is commodified by altering the initial meanings and values (Shepherd, 2002). Locals are forced to live and behave in particular conditions to meet tourists' expectations (Bauer, 2008). Bauer (2008) mentions when locals try to emulate tourists whether in lifestyle, behavior, or languages. They constantly stir up the 'demonstration effect' in which local communities might lose their cultural identity and changes in traditional lifestyles. It could be argued that some sacred areas, sites, or practices may not be respected when these objects become a part of tourism commodities. Indeed, a double discourse of value is always shadowing this practice,

"on the one hand, Smith explains in Detloff (2016), there is the discourse of economic theory: money, commerce, technology, industry, production and consumption, workers and consumers. On the other hand, there is the discourse of aesthetic axiology: culture, art, genius, creation, appreciation, artists, and connoisseurs."

VR offers a more sustainable way of traveling (Schaffer et al., 2018) where users can appreciate the environment and socio-cultural aspects of locals without degrading them. Still, one might quite naturally question the economic viability of local people. According to Guttentag (2008), host community members involved in tourism, such as tour guides, tour operators, restaurant owners, hotel employees, and souvenir vendors, would face a dearth of real clients. This may affect the economic perspective of locals who mostly rely on physical tourism activities as their main income. Hence, an alternate form of income should be developed to support the host community during the pandemic (Itani \& Hollebeek 2021). Perhaps marketers can recognize the possibility to translate VR content into a purchase intention while maintaining the magnetism of real traveling and encouraging those wandering thirst to travel (Sarkady et al., 2021).

\section{The authenticity of virtual reality experiences}

Low consumer confidence and slow virus containment during the pandemic have become some of the components that weighed International tourism recovery (UNWTO n.d.). Fearing the risk of the virus spreading during vacation may freeze tourist motivation to visit new places. Virtual reality could help to open the possibilities for users to visit desirable destinations without worrying about the pandemic. VR may promote the health and safety of travelers as they virtually travel to various destinations from home (Chirisa et al., 2020). One destination that has used artificial intelligence in its tourism-related activities is Uluru Kata Tjuta National Park Australia (Parks Australia n.d.). Through virtual reality, users may experience the geographical aspects of UKTNP without personally visiting the place (Parkaustralia.gov.au n.d.). VR allows virtual visitors to encounter a dynamic 360-degree visualization with vivid imagery that 
represents geologic features such as caves, cliffs, rocks, and several plants including local faunas (Schaffer et al., 2018; Parkasaustralia.gov.au, n.d.). Together with audio clips and natural sound effects, VR helps users to feel the atmosphere of the site or evoke a sense of being there (Schaffer et al., 2018). This instrument might be considered as a remedy for travelers who seek excitement and the intensity of the experience during the pandemic. In Indonesia, for instance, to bring back travelers confidence, the authorities have developed virtual tours of sites and attractions across the country. It enables users to explore the beauty of Indonesia through the use of VR. This includes 360degree images and the advanced version of 360-degree videos (Indonesia.travel, n.d.). This technological advancement may help to stimulate a desire for traveling and keep postponed tours fresh in people's memories (Dupeyras et al., 2020). Inevitably, the authenticity of the VR experience is the determinant of the intended use of this technology in the tourism context (Schiopu et al., 2021). People are traveling owing to their desire for seeking the newness and excitement of the experience (Li \& Petrick, 2008). A positive tourist experience may assist tourists to initiate an emotional attachment and a positive relationship to places that correlate with their positive experiences (Ramkissoon et al., 2013). It creates a lifetime memory that can be shared, re-called, and re-lived (Schaffer, 2018). Though VR might mitigate the contagion of the virus and help the industry to be more sustainable, some elements still cannot be covered. As humans tend to use their sensory systems such as smell, touch, or taste to interact with the product and to influence their decisions (Solomon et al., 2019). Some would argue that VR provides no interaction or limited interaction. As it is led through systematically computerized 360-degree videos and images (Chen, 2020). Furthermore, VR experiences only take quite a few minutes far from the real vacation which can take more than a week (Chen, 2020).

Therefore, this technological advancement may not appeal to those who seek adventure and the authenticity of attractions (Chen, 2020). However, the involvement of good governance and marketing strategies may perhaps become a game-changer for destinations in utilizing this artificial intelligence (Chen, 2020; Chirisa et al. 2020). As technology continues to advance perhaps it can make use of other sensory information and generate an environment with a higher degree of interactivity (Chirisa et al. 2020). Also, within the realm of possibility, it may help to promote and sell the sites for potential tourists. Helping potential tourists to make fully informed decisions and reasonable expectations before visiting. This statement is supported through some studies done by Shaikh et al. (2018); Guttentag, (2010); and Violante et al., (2019) who said that VR applications can highly persuade customer journeys where customers are looking to be inspired. It may therefore help virtual tourists to see how worthy and prospective the sites before visiting.

\section{CONCLUSIONS}

The coronavirus has massively impacted the world. Around 90 percent of the global population now lives in countries with travel restrictions (Serra \& Leong, 2020). Not only the health sector has been strongly affected by this pandemic, but also the economies of the world including tourism industries (Chirisa et al., 2020). Therefore, the use of virtual reality might be considered as a feasible instrument to promote the sustainability of tourist destinations both from environmental aspects and socio- 
cultural values. However, an alternate form of income should be established to strengthen the economic viability of destinations. Furthermore, this technological instrument (VR) may not fully replace the authenticity of physical attraction. But it may help to stimulate user desires for traveling and provide another option for virtual tourists to see how prospective and worthy the site is to be visited after the restriction being eased or perhaps after the pandemic (Dupeyras et al., 2020).

\section{BIBLIOGRAPHY}

Agustina, I. T., \& Yosintha, R. (2020). The Impact of Covid-19 on Hotel Industry In Asian Countries. Jurnal Kepariwisataan Indonesia: Jurnal Penelitian dan Pengembangan Kepariwisataan Indonesia, 14(2), 159-167.

Bauer, I. (2008). The health impact of tourism on local and indigenous populations in resource-poor countries. Travel medicine and infectious disease, 6(5), 276-291.

Chen., A. (2020). Is virtual travel here to stay, even after the pandemic subsides?. Retrieved from, https://www.nationalgeographic.com

Chen, D. (2020, August). Virtual reality vacation offers a new kind of entertainment. Retrieved from https://www.tourism-review.com.

Chirisa, I., Mutambisi, T., Chivenge, M., Mbasera, M., Sidambe, M., Muchenje, B., ... \& Zengeni, D. (2020). Scope for Virtual Tourism in the Times of COVID-19 in Select African Destinations. Journal of Social sciences, 64(1-3), 1-13.

Detloff., M (2016). Introduction: On value. Cambridge University Press.

Dupeyras, A., Haxton, P., Stacey, J. (2020). The COVID-19 crisis and tourism: Response and recovery measures to support the tourism sector in OECD countries. Retrieved from https://www.g20-insights.org/

Edwards., B. (2020). What's the difference between coronavirus and COVID-
19?. Retrieved from, https://www.click2houston.com.

Guttentag, D. A. (2010). Virtual reality: Applications and implications for tourism. Tourism Management, 31(5), 637-651.

Fraenkel, W., \& Wallen, N. E. Hyun,(2012). How to design and evaluate research in education, 8 .

Indonesia.travel. (n.d.). These 5 virtual journeys to Indonesia will take you on an epic adventure while you stay at home. Retrieved from https://www.indonesia.travel

Itani, O. S., \& Hollebeek, L. D. (2021). Light at the end of the tunnel: Visitors' virtual reality (versus in-person) attraction site tour-related behavioral intentions during and post-COVID19. Tourism Management, 84, 104290.

Li, X., \& Petrick, J. F. (2008). Tourism marketing in an era of paradigm shift. Journal of Travel Research, 46(3), 235-244.

Liu, Y. C., Kuo, R. L., \& Shih, S. R. (2020). COVID-19: The first documented coronavirus pandemic in history. Biomedical Journal, 43(4), 328-333.

Mitchell., C. (2020). Virtual reality. Investopedia. Retrieved from https://www.investopedia.com/

Newsome, D. (2020). The collapse of tourism and its impact on wildlife tourism destinations. Journal of Tourism Futures.

Parks Australia. (n.d.). Virtual Tour. Retrieved from https://parksaustralia.gov.au/uluru/dis cover/virtual-tour/

Ramkissoon, H., Smith, L. D. G., \& Weiler, B. (2013). Relationships between place attachment, place satisfaction and pro-environmental behaviour in an Australian national park. Journal of Sustainable Tourism, 21(3), 434-457.

Sarkady, D., Neuburger, L., \& Egger, R. (2021). Virtual Reality as a Travel Substitution Tool During COVID-19. In Information and Communication Technologies in Tourism 2021 (pp. 452-463). Springer, Cham. 
Schaffer, V., Bec., A, Moyle., BD. \& Scott., N. (2018). VR technology gives new meaning to 'holidaying at home, but it is really a substitute for travel', The Conversation, 15 October. Retrieved from https://theconversation.com

Schiopu, A. F., Hornoiu, R. I., Padurean, M. A., \& Nica, A. M. (2021). Virus tinged? Exploring the facets of virtual reality use in tourism as a result of the COVID-19 pandemic. Telematics and Informatics, 101575.

Serra, A., \& Leong, C. (2020). Here's what travelling could be like after COVID19. Retrieved from https://www.weforum.org/

Shaikh, S., Bokde, K., INGALE, A., \& Tekwani, B. (2018). Virtual Tourism. International Research Journal of Engineering and Technology, 5(4), 2044-2046.

Shepherd, R. (2002). Commodification, culture, and tourism. Tourist Studies, 2(2), 183-201.

Solomon, M., Russell-Bennett, R., \& Previte, J. (2019). Consumer behaviour. Pearson Higher Education AU.

UNWTO. (2020). Impact assessment of the COVID-19 outbreak on international tourism. UNWTO. Retrieved from https://www.unwto.org/impactassessment-of-the-covid-19outbreak-on-international-tourism

UNWTO. (n.d.). International Tourism and COVID-19. Retrieved from https://www.unwto.org/

Violante, M. G., Vezzetti, E., \& Piazzolla, P. (2019). How to design a virtual reality experience that impacts the consumer engagement: the case of the virtual supermarket. International Journal on Interactive Design and Manufacturing (IJIDeM), 13(1), 243-262.

Wang, N., Li, S. Y., Yang, X. L., Huang, H. M., Zhang, Y. J., Guo, H., ... \& Shi, Z. L. (2018). Serological evidence of bat SARS-related coronavirus infection in humans, China. Virologica Sinica, 33(1), 104-107.

WHO. (2021, February). WHO coronavirus disease (COVID-19). WHO. Retrieved from https://covid19.who.int/

WHO. (n.d.). Middle east respiratory syndrome coronavirus (MERS-CoV). WHO. Retrieved from https://www.who.int/healthtopics/middle-east-respiratorysyndrome-coronavirus-mers 